\title{
Knowledge and Power in a Pastoral Landscape: Agrarian Struggles in Southern Matabeleland
}

\author{
Dr Clifford Mabhena \\ National University of Science and Technology: Institute of Development Studies
}

\begin{abstract}
The Fast Track land Reform and Resettlement programme embarked on by the Zimbabwe state since 2000 has seen vast tracks of land expropriated from former commercial farmers. The justification being that there was an uneven distribution of land between the white settler community and the indigenous people. The village type resettlement and the small 'commercial farms' models, have been adopted by the state and applied across the whole country without taking into consideration varying landscapes of provinces. The focus of these models is provision of arable land, a situation suitable for a better rainfall region such as Mashonaland and not necessarily the dry Matabeleland region A hegemonic tendency by the post colonial state in Zimbabwe has seen reduced livelihoods for Southern Matabeleland residents. Programmes and projects viewed as workable in Mashonaland have been brought 'top-down' to the region despite resistance by most residents. State land re-distribution has over the years been biased towards acquisition of land for village settlements and crop farming, based on political and technocratic plans designed for Mashonaland provinces. Southern Matabeleland is a dry and live-stocking region, and therefore prefers land re-distribution programmes that give prominence to grazing land. Provincial plans that at least capture interests and needs of the people have been given marginal attention by the state and its apparatus, resulting in development projects that do not address livelihoods of the larger population of this region.In this article, I argue that state land re-distribution in southern Matabeleland has not addressed the felt needs of people in Matabeleland South because of the inappropriate hegemonic models of the state and its institutional apparatus. People pin their hopes on livestock for a livelihood and therefore, land re-distribution should address the issue of grazing more than village settlements and crop farming
\end{abstract}

\section{Introduction}

Development discourse in most Third World countries has largely been shaped by state apparatus. The notion that a development programme or project applicable in one part of the country is applicable to others has seen development programmes imposed on a completely different landscape; and this is not a new phenomenon in development discourse. Misreading a landscape can either be a coincidence, a misrepresentation, or misunderstanding of that particular landscape Fairhead and Leach (1996). In some instances such as southern Matabeleland has been done deliberately. The land reform programmes that have been rolled out by the state in Zimbabwe since independence have been biased toward village settlements and crop farming (Jocelyn 1991, 2003, Marongwe 2003, McGregor 2002). One will argue that geographical research that has been done over the last hundred years has classified southern Matabeleland as a dry region falling in climatic agro regions IV and V, basically suitable for ranching (Chatora 2003, Moyo 1995). However hegemony by the state and its development apparatus has misrepresented this evidence by exercising power and authority over resettlement models in this region.

The state has constructed an imaginary target population and target area by misrepresenting knowledge in order to consolidate its hegemony. Inappropriate development models such as the AI and A2 have not appealed to people from this region, but continue to dominate the land redistribution agenda. Livestock livelihoods constitute a larger component in the way of life of southern Matabeleland residents and for one to negate this notion does it at his/her programme's peril (Ranger 1999). Of course recent research has indicated that agrarian livelihoods are dwindling and are fast being replaced by off farm livelihoods. In southern Matabeleland the effects of the Economic Structural Adjustment Programme (ESAP) coupled with inappropriate resettlement models have driven most able bodied household members to activities such as gold panning and migration as alternatives to the traditional agrarian practices (Moyo 2000c). Here, I argue that the pursuant of these alternatives is a result of misinterpretation by state apparatus of the knowledge and needs of this target population and target area. Jocelyn (1991) concluded in her comparative study of Insiza district of southern Matabeleland and Manicaland, that the limited incidences of 
Knowledge and Power in a Pastoral Landscape: Agrarian Struggles in Southern Matabeleland

squatting on commercial farms in the 1980s into the 1990s was evidence that the target population had no immediate interest on village resettlement. Instead most communal areas livestock owners reacted to the demand for land by poach grazing livestock in abandoned, state and commercial farms showing their preference of a resettlement model that addresses issues of grazing land. The Fast Track Land Reform Programme introduced in 2000 had the capacity to address grazing needs of communal areas as more land was made available through expropriation of most former commercial farms. However, I argue that the capacity the FTLRRP had on improving communal area livelihoods had been jeopardized by the type of models implemented. In earnest, the FTLRRP had reduced agrarian livelihoods of residents of southern Matabeleland.

\section{The 'Lagisa' Model And Multiple Livelihoods}

Even prior to state driven land reforms people of this region relied on the 'lagisa' system of livestock husbandry (ENDA Zimbabwe 1995:7, Nyathi 2000). This system entailed livestock owners grazing their livestock in common land along the Shashe and Thuli rivers during winter months. This common land was not part of everyday grazing land around the villages but a special area for relief grazing. It did not take into account social and political affiliation but was regarded as land for every livestock owner at a particular time of the year. The long distances to emlageni forced herd men to camp out there and probably alternate depending on the availability of able bodied men in the household ${ }^{1}$. In some cases a group of herdsmen could be hired by a kraal, village or ward to look after the livestock. The introduction of the FTLRRP was viewed as an opportune moment for communal livestock owners to reduce that distance by occupying acquired commercial farms. As I will argue latter on, the adjacent farms that communal livestock owners had lease grazed, poached grazed and earmarked for grazing ended up either being new village settlements or A2 farms. This in turn resulted in some household members seeking new livelihoods in gold panning and migrationAlthough livestock are regarded as the main agrarian livelihoods, crop farming has not been forsaken, but has been limited to small fields as a result of the unpredictable rainfall. Development agencies have encouraged the growing of small grains that are drought tolerant, but have met little success in discouraging these farmers from growing maize. Maize is generally regarded as staple food ${ }^{2}$. Literature reveals that people of southern Matabeleland engage in other activities to earn a living. Remittances from household members working in urban factories, mines and out side the country constituted and still constitute a large portion of livelihoods (Nyathi 2000). It is a fact that because of the economic melt down and dwindling urban jobs, there has been reversal from the rural-urban migration of the 1980s and early 1990s to the now common urban -rural migration. Migration to other countries is enormous in southern Matabeleland probably because of its proximity to South Africa and Botswana. In the study area $85 \%$ of households had more than one member working either in South Africa or Botswana

\section{State hegemony in southern Matabeleland}

Masipula Sithole (2000) contributing to the book; The Uncertain Promise of Southern Africa, acknowledges that Zimbabwe has experienced two Authoritarian regimes; one colonial spanning 90 years and the other Post colonial from 1980 to date. The post colonial regime has been more heavy handed on Matabeleland since the discovery of arms caches in the former ZAPU owned farms; and with mistrust that has always been prevailing between the two parties ${ }^{3}$, ZANUPF predominantly Shona, and drawing most of its support from Mashonaland provinces, and ZAPU drawing its support from the Ndebele who occupy the two Matabeleland provinces and part of the Midlands; the arms cache discovery was an opportune time to demonstrate supremacy of the Shona over the Ndebele $^{4}$. The lashing out of the Gukurahundi following the arms discovery instilled a sense of fear and most Ndebele had to accept the hegemony of the Shona.

Alfred Stepan in his studies of authoritative regimes mentions five groups in the regime. The first group is the core supporters of the regime who are characterized by a siege mentality and will see opposition as a 'clear and present

\footnotetext{
${ }^{1}$ See ENDA Zimbabwe 1995 study of Mlambapele communal area of Gwanda South

${ }^{2}$ UNDP Vulnerability Assessment 2006

${ }^{3}$ See Pathisa Nyathi (2000:148): Alvord Mabena. The Man and his Roots, A Biography

${ }^{4}$ See Pathisa Nyathi (2000:249-50): Alvord Mabena. The Man and His Roots, A Biography
} 
danger' to their interests. These will actively support repressive measures against any opposition (Stepan cited in Sithole 2000:68). The coercive apparatus that maintain the regime in power forms the second group of the regime supporters. In this group are the military and security forces that tend to strongly identify the interest of their organisations with those of the political regime. In the case of Matabeleland the fifth brigade (Gukurahundi) ${ }^{5}$ acted in that fashion. There were pursuing the interests of their political superiors in the regime as will be discussed later on. The third group identified by Stepan is the regimes passive supporters...these will submit to authoritarian hegemony under the weight of the first two groups and mostly in this category are the middle class and they will remain 'quiescent and pliable', and may even be used by a 'cohesive and self confident authoritarianism (2000:68). The last two groups identified by Stepan are the active opponents of the regime and the passive opponents of the regime that are regarded as the regimes detractors-the opposition.

From Stepan's typology, residents of Matabeleland fall predominantly in the last two groups and this created uneven development between Matabeleland and Mashonaland. Even when the land reform was instituted in the early years of independence Matabeleland did not benefit as much as Mashonaland, and suffice to say at this juncture, that people from the Mashonaland provinces occupied resettlement schemes in Matabeleland, a scenario that could not pertain in Mashonaland; and hence hegemony continued unabated. The Fast Track Land Reform programme did not spare residents of Matabeleland this hegemony as productive farms were allocated to the active and coercive supporters of the regime at the expense of deserving residents of Matabeleland ${ }^{6}$. The unity accord of 1987 ushered a new era whereby the absorbed ZAPU leadership had to convince its supporters to support the regime despite the suffering they had endured under Gukurahundi. The fast track land re-distribution although provided residents of Matabeleland with an opportunity to increase their land holdings after government expropriated former commercial farms; the model of re-distribution was designed at central level and did not consider the geographical, cultural differences, and preferences between Mashonaland and Matabeleland ${ }^{7}$. As already mentioned earlier on, people in this region are generally pinning their livelihoods on livestock farming and therefore any land reform programme should address live-stocking needs. Following Stepan's assertion of active supporters, the unity accord created more active supporters of the regime from Matabeleland and in the making; these supporters also pursued hegemonic tendencies (Jocelyn 2003).Cooke points out that:

"Coercive persuasion suggests that participation can indeed be co-opted for a range of agendas other than those with the needs of the poor and oppressed at heart...It also suggests that participatory development with an espoused and genuine commitment to meeting the needs of the poor and oppressed and to raising their consciousness on the part of the change agent are not in themselves...a safeguard against disastrous outcomes from participatory development" (Cooke 2001:121). The assertion by Cooke is true for southern Matabeleland as is argued later on in this presentation.

\section{Methodology}

Evidence and arguments in this article are based on fieldwork I conducted in southern Matabeleland. I purposively sampled the districts of Gwanda and Umzingwane taking into account their vulnerability to these state driven resettlement models among other variables. I conducted field interviews with conveniently selected respondents and informants from 2007 to 2009. An interview guide capturing the key themes of land access, livelihoods, coping strategies and safety nets guided me in interviewing my informants. I held a number of focused group interviews; carried participatory and non-participatory observations; in addition to research studies conducted in the $\operatorname{area}^{8}$, and photography. I had to trade cautiously as the land question was sensitive an issue and topical in development practice in Zimbabwe by then.

\section{Politics of land distribution in the 1980s into the $1990 \mathrm{~s}$}

The land tenure system in Matabeleland South province prior to the 2000 Fast Track Land reform programme was the same as the rest of the country. There were communal areas (including common grazing land), resettlement areas, irrigation schemes and white commercial farms. Commercial farms owned by whites and blacks were regarded as private property whereas other models were regarded as state land (Chatora 2003, Moyo 1995, Jocelyn 1991, Ranger 1999). In an effort to address colonial imbalances and to be seen as non-partisan, the state

\footnotetext{
${ }^{5}$ Gukurahundi is a traditional Shona word that refers to early rains that wash away the chuff, and in this presentation refers to the army brigade that was unleashed in Matabeleland in the 'overt sphere' of fighting dissidents and in the 'covert sphere' of eliminating the Ndebele ethnic group.

${ }^{6}$ Fieldwork interviews and observations 2005-2007

${ }^{7}$ UNDP, 2002.Zimbabwe. Land Reform and Resettlement: Assessment and Suggested Framework for the Future. Interim Mission Report.

${ }^{8}$ Particular reference is made to the study done by Alexander Jocelyn (1991). This is one of the very few studies on agrarian struggles done in southern Matabeleland
} 
bought resettlement farms for re-distribution in Matabeleland. In 1980 and 1981 there were relatively few people in Matabeleland who moved from communal areas to the formerly European areas, reflecting a locally perceived shortage of grazing land and the dearth of abandoned ranches (Jocelyn 1991:581). People in Matabeleland believed the village resettlement model was not suitable for their livelihoods as they depended on livestock for a living; and therefore to raise their skepticism on the resettlement model resisted government planned village settlements and demanded a resettlement model that gave preference to grazing land. Jocelyn (1991) contends that the ZANUPF dominated government interpreted local demands as subversive and prevented the development of a patron-client relationship that was vital for the control of the region ${ }^{9}$. Unlike Mashonaland where a large number of people had already settled on commercial farms as squatters, squatter occupations of commercial farms were rare in Matabeleland. Jocelyn concludes that Matabeleland as a cattle economy was not suitable for squatting; and in an endevour to show discontent with the resettlement model communal cattle owners responded to perceived shortage of grazing, rather than arable land by poach grazing on neighbouring farms (Jocelyn 1991:582). In most cases these neighbouring farms were either abandoned during the liberation war of the 1970s or recently bought by the Zimbabwe state.

Poach grazing by communal dwellers was regarded illegal by government officials and led to clashes with these officers. The officers were under instruction to implement a village based model that took cognizance of crop production as the main activity in these farms. The resistance by residents of this region was done a blow by the drought during the 1980s as the latter left rural residents dependent on government food relief. The drought presented an opportunity for state officials to intensify their hegemony as those who did not follow their instructions to move to village resettlements were deprived of the much needed food aid. The drought also presented a strong argument for residents of this province as they demanded more grazing land to cushion their cattle from dwindling pastures in communal grazing areas. In response to their demands, government through a parastatal, Cold Storage Commission, launched Operation Cattle Rescue and purchased almost $Z \$ 6 \mathrm{~m}$ worth of cattle from communal areas between January and May 1982. This was devastating as communal farmers keep livestock for other purposes like manure, draught power and traditional ceremonies. Jocelyn (1991) observed that even the Deputy Minister of Lands and Resettlement, a descendant of Matabeleland, stressed that making land available for grazing would benefit people with cattle at the expense of the landless without cattle (Herald, 1982). The utterances by Mark Dube, the Deputy Minister, received strong criticisms from ZAPU District Councillors especially those from Gwanda district. One district Councillor after the other rose in one meeting to demand that resettlement priorities be reversed to give priority to grazing land. One councilor quoted in the Herald October 1982, exclaimed in the meeting with the Deputy Minister of Lands and Resettlement:

"Cattle raising is our life blood. We would rather stay crowded in communal areas and let the purchased farms be used for grazing." Jocelyn (1991) cites one councilor responding to Mark Dube's plea for cooperation and protection of resettlement officers from dissidents: "The intimidation of the resettlement officers is not our responsibility until we get grazing land for our cattle. Don't talk to us about policing this area. We will do so as soon as we have been given more land for grazing" (Jocelyn 1991:588).

Unlike Mashonaland, land availability in Matabeleland was limited as there were few abandoned farms at independence let alone new ones bought by the state on a willing seller willing buyer basis (Jocelyn 1991, McGregor 2002). Jocelyn (1991) concludes in her study that lack of abandoned land, the pattern of squatting and the unpopularity of village resettlement models constrained land re-distribution soon after independence in Matabeleland. Jocelyn found that by 1981, the province accounted for only $10 \%$ of land acquired... as a result of a small number of abandoned farms compared for example with 583 acquired farms in Manicaland. This conclusion also demonstrates the discrepancy of the policy of willing seller/willing buyer since a majority of purchased land was abandoned; by implication occupied white commercial farms were safe if owners were not willing to sell. Because of the resistance by people from this region to move into village settlements on newly acquired farms; a majority of those settled in the acquired farms were drawn from the ranks of workers formally employed in abandoned farms and mines. In most cases these people were alien of either Malawian or Zambian origins that had no claim to communal land (Jocelyn and McGregor 2001). Some people were directly recruited from other provinces to occupy resettlements in this region. The resettlement of former farm and mine workers and outsiders created animosity toward the schemes among communal area cattle owners and their clients who claimed the land on the basis of need and historical rights.

\footnotetext{
${ }^{9}$ See also Goran Hyden 2006:72, the economy of affection; African Politics in Comparative perspective. Goran Hyden concludes that in most African countries the state is bent on creating a patron-client relationship in order secure patronage and political support of the peasants
} 
The resistance by people of Matabeleland was further indicated by the low numbers that applied for resettlements. For instance the 'Herald, October 1982' revealed that only 2, 7\% of 88000 had responded to the circulation of resettlement forms in Matabeleland South. The low turn out was blamed on councillors who the ministry of land official said hoarded the forms; chiefs who wanted to move as a group with their followers, and most important, the fact that the people in Matabeleland did not agree that the resettlement scheme worked by the government would address their problems, mainly grazing. The same paper reported that the government was having a second look (because) the agriculture oriented scheme, while suitable to regions in Mashonaland, might not be entirely satisfactory in the stock oriented Matabeleland (Herald, 1982)

The years 1983 to 1987 were difficult for people in Matabeleland. As alluded to earlier on; the government was engaged in a massive repression of the inhabitants of this province in the 'overt sphere' of weeding out dissidents (Jocelyn, McGregor and Ranger 2000). During this period, the repression of the civilian population and their local and national leaders effectively denied Matabeleland a voice in decisions concerning development and land distribution (Jocelyn 1991:588). Jocelyn 1991 argued that the imposition of unpopular councillors by the government created further resistance in terms of taking offers for resettlement by a majority of communal residents of the province. Although communal farmers were deprived of grazing land in the resettlement farms, the terrorization of resettled people, ranchers, and resettlement officers provided a relief to communal farmers as they could graze their livestock under the protection of dissidents. During this period, a number of farms in Matabeleland were put for sale as the commercial farmers fled the dissident menace. Some new supporters of the regime grabbed this opportunity to lease vast tracts of land that had been willingly sold by the fleeing commercial farmers. Most of these supporters were either new councillors or Members of Parliament elected on a ZANUPF ticket. Because of the persistent drought, let alone inadequate stock, these new supporters of the regime lease grazed some of their paddocks to communal livestock farmers.

One can conclude that the period 1980 to 1987, with the devastating drought and havoc caused by dissidents, provided an opportunity for communal farmers to intensify poach grazing in commercial farms. Even the state became supportive of lease grazing as it was difficult to control the activities of dissidents. In other words it can be concluded that dissidents played a key role in expressing communal objection to the resettlement models by attacking those in resettlement areas. Some commercial farmers had reached an understanding with communal livestock farmers; for instance on Hollins Block resettlement in Gwanda, communal cattle owners had been allowed access to the land by the commercial rancher. With the resettlement, outsiders were brought in who tried to exclude communal cattle. In response scheme fences were cut, its villages burnt and communal cattle driven on in a battle which continued up to 1986 (Jocelyn 1991:592). Furthermore, the state used drought relief as a 'carrot and stick' tool to gain some form of compliance from communal farmers from Matabeleland. The carrot and stick scenario made it difficult for people from this region to withdraw from this hegemony. As Jocelyn puts it; their autonomy, and thus their ability to resist or press claims were severely limited (Jocelyn 1991:591). Isaacman (1989) argues that the partial autonomy of the peasantry, derived from their command over subsistence, partial control over their own labour and direct access to the instruments of production; is key to resistance to the claims of the state and appropriating classes. The signing of the unity accord between ZAPU and ZANUPF in 1987 brought some form of peace and stability in Matabeleland region (Banana 1995). The signing of the agreement ushered a new era in the development discourse of the region. With ZAPU councillors back at the helm of councils in the region, more pressure was put on the united party to deliver basing on the interests of the inhabitants of the province. In an attempt to appease the people of Matabeleland, especially senior politicians, the state leased out unsettled farms to politicians, civil servants and parastatals. In Gwanda and Insiza districts of the province vast tracts of land were leased to the Cold Storage Commission which acted as a breeding haven for restocking communal herds that had been depleted by the drought ${ }^{10}$. A notable observation was that among the civil servants who benefitted from farm leasing were those from outside Matabeleland and this did not augur well with communal cattle owners though they could not raise an issue since ZAPU had agreed to the unity terms that among other things, very particular on national unity irrespective of ethnicity. Communal cattle owners lease grazed their cattle for a fee in these unsettled farms. Although the state was still keen on Model A resettlement (villagisation), even after the unity accord, residents of southern Matabeleland did not take allotments as expected. For instance by 1989, two years after the signing of the accord only 1878 families had been settled on $44 \%$ of the then 503,671 ha purchased for resettlement

\footnotetext{
${ }^{10}$ Interviews in 2005 revealed that the CSC scheme was full of corruption and very few people in the research area benefitted before in collapsed under ESAP.
} 
Knowledge and Power in a Pastoral Landscape: Agrarian Struggles in Southern Matabeleland

(Jocelyn 1991). This is indicative that people of the region were not prepared to leave their communal areas to these new farms.

As alluded elsewhere in this article people of Matabeleland are generally pastoralists and believe a workable resettlement model should decongest communal areas in terms of livestock not in terms of people or homesteads. The delay in apportioning land for grazing to communal cattle owners created largesse for politicians and civil servants who leased out some of the state farms to cattle owners from communal areas. This created problems as some cattle owners could not afford rents charged by these cronies, especially in the early 1990s when the region was hit by a severe drought. In an attempt to satisfy the wishes of the people of this region, government touted an alternative resettlement model to replace the contentious model A resettlement and dubbed it model D. Model D according to Chatora (2003) was cattle oriented and piloted in the dry parts of southern Gwanda district. In this model, ranches were to be used for rotational grazing while the beneficiary communal areas were reorganized into a complex of planned villages, demarcated arable areas and paddocked grazing land. However as Robin, 1994 found, movement of $90 \%$ of villages was rejected by beneficiaries and this resulted in the cutting of paddock and demarcation fences. In Thuli $11 \mathrm{~km}$ of fence was cut and $24 \mathrm{~km}$ of fence in Doddieburn. The other set back of model $\mathrm{D}$ was the issue of destocking to match the land carrying capacity which was vehemently rejected by the intended beneficiaries. Destocking was viewed by people of this region as remiscent of the colonial days when large numbers of livestock were culled, and some commentators view destocking as one of the major causes of the war of liberation.It is not surprising that during the early 1990s some black farmers bought farms as a large number of white commercial farmers were scaling down operations in the aftermath of the expiry of the willing seller/willing buyer clause of the Lancaster House agreement of 1979. The other militating factor in the early 1990s was the enactment of the Land Acquisition Act (1992) and the rhetoric that government may soon compulsory acquire land as it deem suitable. Pre-occupied with the challenges of the Economic Structural Adjustment Programme (ESAP), the state did not vigorously persue the land distribution programme until the year 2000, when it embarked on the Fast Track Land Reform and Resettlement Programme (Moyo 1995, 1999, 2000a). Some commentators argue that, the Zimbabwe government did not actively implement the Land Acquisition Act (1992) as a strategy not to derail democratic talks in South Africa. Some view the delay due to more pressing economic issues that had been brought about by ESAP. The 1990s decade had numerous challenges for the state ranging from massive retrenchments in urban factories and successive droughts, to highly charged mass actions by trade unions and university students (Phimister and Raftopoulos 2000). War veterans also claimed recognition for their participation in the war of liberation in the 1970s and hence government was forced to commit Z\$50 000 per each of an estimated 40000 war veterans and Z\$2000 monthly pensions in an unbudgeted expenditure. This resulted in the depreciation of the Zimbabwe Dollar, resulting in untold suffering for the peasantry, workers and the unemployed. The government's ambitious excursion into the Democratic Republic of Congo (DRC) to propel the Laurent Kabila's government also strained the already strained national treasury, resulting in massive demonstrations against the leadership of ZANUPF (Kriger, 2001; Alexander et al 2000, Moyo, 1998:5, Moyo 2001).

As a way of legitimizing the compulsory acquisition of white commercial farms, the government drafted a constitution in 1999, with a close calling for the compulsory acquisition of white owned farms with only compensation for improvements on the land, not the land itself. The draft Constitution was put to a national referendum in February 2000, and Zimbabweans voted 55\% against the draft and 45\% for the draft (Rich Dorman, 2001:218-223). The ZANUPF government pointed fingers at the newly formed Movement for Democratic Change (MDC) and white commercial farmers as having influenced the outcome of the referendum. Thus, two weeks after the results of the referendum, war veterans and ZANUPF Militias invaded white owned farms and claimed that they were repossessing their ancestral land stolen by grand parents of white farmers in the $19^{\text {th }}$ and $20^{\text {th }}$ centuries (Jocelyn 2003:99). By July 2000, the government officially launched the much talked about Fast Track Land Reform and Resettlement Programme.

\section{The Dilemma Of The Fast Track}

In a detailed ethnographic study of the effects of land reform in Matabeleland, I found that even the introduction of the Fast Track Land Reform and Resettlement Programme did not spare the residents of Southern Matabeleland the dominance of State apparatus in the distribution process. As indicated earlier on, the state did not consult local leaders let alone would -be beneficiaries of this programme. One resident commented about the programme as follows: "We were deprived of grazing land during the dissidents' era of the early 1980s. We believed the cessation of hostilities between our party ZAPU and ZANU would at least address our needs for grazing land that did not happen. Then came the Fast Track in 2000, but alas, the state further promoted villagisation against our 
Knowledge and Power in a Pastoral Landscape: Agrarian Struggles in Southern Matabeleland

wishes. I am very disappointed because the land we thought we have secured when Mr. Hunt's farm was taken over was turned into a village settlement and the adjacent paddocks which we used to lease graze in early summer from Mr. Hunt have been allocated to a senior politician who does not come from this area and he does not understand when we tell him that we used to lease graze our cattle there since Thuli river flows through and is the only reliable source of water for livestock during dry months of the year. We were given three paddocks by the land committee as a gesture to silence us but these paddocks are not enough bearing in mind that the whole of Wenlock communal land has to graze their livestock there. We voiced concern to the authorities, asked for part of Konongwe farm and we were promised. To our surprise in early 2001 we were surprised to learn that Konongwe farm has been designated an A2 farm that has been allocated to Mr. Mringa from Manicaland province. Really though there has been unity, we feel rejected by the very government that is claiming to care for our livestock needs. Surely without adequate grazing we are nothing as a people," (Mbhoda Dube-interviewed 15/12/05).

The sentiments raised by Mr. Dube indicate that although land has been made available after the expropriation of white commercial farms, people of southern Matabeleland have not benefitted as they en visaged. The state's top down approach to land re-distribution has not changed from what happened in the 1980s and 1990s. The state still detects on the type of redistribution models and in the making marginalizing the residents of this region. Those active supporters of the regime who do not even come from the region are benefitting at the expense of the rightful beneficiaries. As an act of sabotage as viewed by informants and respondents I interviewed, the allocation of A2 farms is also biased toward those aligned to the ruling party irrespective of whether they have livestock or not. For instance one old man with 70 herds of cattle in Lushongwe communal area cried foul of the state's failure to allocate him a farm because he was not an active member of the ruling party. Some informants who are active members of the ruling party also voiced concern on the hectarage offered on these A2 farms. Mr. Mpofu an active supporter of the ruling party had these strong words about his farm size:

"My son I actively participate in the land committee meetings and have raised concern on the non-viability of 400-1000ha per A2 farmer in this region, but what we hear is that the hectarage was decided at National level and there is nothing the Land Officer can do to increase the hectarage. This is unacceptable because surely one can not graze 100 cattle on this hectarage without causing environment degradation. Traditionally we are extensive livestock keepers hence we need more than a mere 400 to 1000ha for us to benefit from this land programme; otherwise I see a lot of the new A2 farmers resorting once more to poach grazing like what we did during the era of white commercial farmers. There is plenty of idle land but the state is not forth-coming to alleviate our plight. We used to graze our cattle at 'emlageni' during the dry months and thought the land reform would spare us the burden of travelling long distances to graze our cattle at 'emlageni'. If this issue is not addressed immediately we will be left with no choice but to start over again the 'lagisa' system probably in these unoccupied farms (Mpofu interviewed 12/08/05).

\section{Policy Deficiency:}

The above cases highlight a major policy deficiency toward land distribution in southern Matabeleland. People of this region are basically pastoralist and eke out a livelihood from livestock. For decades people of southern Matabeleland had survived on livestock and had developed adaptive strategies to survive on this arid land. Fieldwork revealed that these people have adaptive strategies such as multi-species livestock husbandry. This implies that southern Matabeleland residents keep livestock such as cattle, goats, donkeys and sheep. Small stock such as sheep and goat is normally disposed off easily to meet immediate livelihoods. In this case, communities exchange livestock such as goats and sheep for either cash or grain since the climate does not favour cropping. In some cases small stock could be used to acquire cattle through barter trade.

In order to survive and manage their livestock southern Matabeleland residents traditionally practiced a grazing system referred to as 'lagisa' implying sending out cattle to common land along the Shashe and Thuli Rivers. As illustrated by Mpofu in the above case people grazed their livestock as a unit and managing that activity was the responsibility of every household head. The chief or headmen would decree that from July to November livestock could be sent to 'emlageni' and that was followed. The constraining factor was the long distance to 'emlageni. It is clear from this response that people would not mind being allocated 'common land' as an alternative model of land redistribution in this area. I therefore argue that the Fast Track Land Reform and Resettlement Programme of year 2000 could have increased rural livelihoods of Southern Matabeleland residents had it followed the 'lagisa' principle rather than the current A2 resettlement model. The 'lagisa' principle is accommodative and does not segregate on political affiliation. It is worth noting that livestock is a source of wealth 
and investment among residents of this region and therefore a programme depriving them access to grazing land is futile.

Another institutional deficiency that has seen residents viewing the land reform programme as lacking in mitigating their plight are the extension policies currently in place. In the first 14 years of independence Animal Health policy was that the department of veterinary services provided animal medicines for free and later on at subsidized costs ${ }^{11}$. Of course this created a dependency syndrome. With the policy shift to $100 \%$ purchase by cattle keepers; and the escalating costs of medicine, a majority of cattle owners have forsaken the idea of dosing their cattle as advised by extension workers. This has resulted in a number of livestock deaths ${ }^{12}$. This, my informants argue, if the state could provide seed packs as a mitigating measure in cropping regions why not forget about distributing seed handouts in this region and provide livestock medicines?The argument raised by residents of this region is valid as Ferguson (1990) argued that development apparatus fail to achieve their targets because of failure to identify the interests of the target group. The interests of people in this region are livestock husbandry more than cropping. One of my informants even suggested that the idea of 'private buyers' deciding on the price of livestock had seen a lot of people not disposing off their livestock as perceived by the state policy of 'open market'. This has been aggravated by the fact that these buyers are usually the same cronies who hold vast tracts of land acquired through the Fast Track land reform programme and their focus is to maximize wealth and exercise power. They tend to forget that people in this region keep livestock for other purposes either than investment or wealth. My informants argued that livestock is also kept for social ceremonies such as lobola and rituals; and are as well symbols of ancestral spirits. Therefore selling livestock, especially cattle is only done as a last option.Ferguson (1990) found that people of Thaba Tseka (Lesotho) would not sell cattle even if the buyer offered more money, the reason being that they value livestock more than money. One of Ferguson's informants even noted that he would rather engage in some other activity to raise money than to sell his ox (Ferguson 1990:146). Ferguson concluded that "it is clear, then, that the fundamental fact is not that livestock are very useful economic investments...or that they are greatly loved and valued for their symbolic connotations...but that livestock and cash are not freely interconvertible. There exists what one might call a one way barrier: cash can always be converted into cattle through purchase; cattle, however, cannot be converted to cash through sale, except under conditions, onditions usually specified as great and serious need for money which cannot be raised any other way, a situation arising from an emergency or from poverty" (Ferguson 1990:146-147).

\section{Conclusion}

Land redistribution is a programme capable of enhancing rural livelihoods if the state identifies the interests of beneficiaries before deciding on the distribution models. Misreading the landscape and misrepresenting peoples' interests brings a danger of embarking on programmes and projects that are not sustainable. People of southern Matabeleland are pastoralists and therefore could enhance their livelihoods if more land is made available for grazing than for villages and cropping. The Zimbabwe state and its development apparatus' relationship and interaction with residents of southern Matabeleland in the past twenty eight years has been characterized by mistrust and the politics of domination, a scenario that has resulted in the region lagging behind in development terms compared to other regions of the country. The 'lagisa' principle is one of the best resettlement models that can remove these pastoralists from the groove of poverty and food insecurity. As argued, the lagisa principle if well applied is capable of solving the problems of grazing land in southern Matabeleland. Misrepresenting knowledge and abusive exercise of power has seen southern Matabeleland lagging behind other regions as state apparatus take for granted that what pertains in Mashonaland should pertain in Matabeleland. This has led to continued agrarian struggles in this region even after the state has expropriated massive tracts of land from former white commercial farmers through the Fast Track Land Reform and Resettlement Programme.

Development practitioners should be aware that programmes and projects that do not address the felt or real needs of the target population are likely to fail to achieve intended outcomes. State hegemony in Matabeleland will only perpetuate the untold suffering the people of Matabeleland have endured since colonization and as a matter of urgency is high time that state apparatus perceive southern Matabeleland as a livestock region and bring on bound livestock related projects to enhance rural livelihoods in this region. Further politicization of land redistribution

\footnotetext{
${ }^{11}$ See World Food Programme 2006 livestock report in Zimbabwe

${ }^{12}$ The introduction of dipping levy had seen a lot of communal areas livestock owners avoiding dipping their cattle as they cannot afford the fees charged. During fieldwork I found out that the Department of Veterinary services was literally not running any dip tanks in the study area and had advised keen livestock keepers to buy dip sprays for their individual herds. Literally dip tanks were malfunctioning in most areas visited and major reason being the prohibitive costs of dipping chemicals.
} 
could lead to misery and insecurity of Ndebeles; a scenario that may lead to people touting the notion of secession. The state cannot be guaranteed of active supporters in southern Matabeleland unless the issue of livestock and grazing land is given prominence in development discourse. Fieldwork data supports this notion as some active supporters of the regime have raised concern on the inappropriateness of resettlement models particularly the Village settlements (A1) and the medium size farms (A2). People of this region will continue suffering for their territory until grazing land is made available. I therefore conclude by noting that land redistribution has a potential to address issues of livelihoods in southern Matabeleland if state apparatus revisit the principle of 'lagisa' as an alternative resettlement model in this region.

\section{References}

[1]. Alexander J (1991): The Unsettled land: The politics of Land Redistribution in Matabeleland-1980-1990. Journal of Southern African Studies Vol. 17, No 4

[2]. Alexander J, McGregor J \& Ranger T (2000) :Violence and Memory One Hundred Years in the 'Dark Forests' of Matabeleland James Currey Oxford

[3]. Bayart J.F, Ellis S and Hibou (1999): The Criminalization of the state in Africa (African Issues). James Currey, Oxford.

[4]. Beach D.N (1980) The Shona and Zimbabwe 900-1850 Mambo press Gweru

[5]. Berry S (1993) No Condition is Permanent: The Social Dynamics of Agrarian Change in Sub Saharan Africa. University of Wisconsin Press Madison

[6]. Catholic Commission for Pearce and Justice (1999): Man in the Middle, Torture, Resettlement, Eviction and Civil War in Rhodesia. Institute for International Relations.

[7]. Catholic Commission for Peace and Justice (1989) Breaking the Silence. Building True Peace. A Report on the disturbances in Matabeleland and Midlands

[8]. Chabal, Patrick and Daloz J.P. (1999): Africa works: disorder as political instrument (African Issues). James Currey, Oxford.

[9]. Chaumba J, Scoones I and Wolmer W (2003): New politics, new livelihoods, agrarian change in Zimbabwe. In review of African Political economy No 98 585-608

[10]. Cousins B, Weiner D and Amin N (1992) Social Differentiation in Communal lands in Zimbabwe. In review of the Political Economy No 53 5-24

[11]. Donham D (1990) History Power and Ideology. Central issues in Marxism and Anthropology. University of California Press. Wisconsin

[1]. Fairhead J (1993) Representing knowledge, the new farmer in research fashions in practicing development Social Science Perspectives Pottier J (ed), Routledge, London and New York

[2]. Ferguson, James (1990): The Anti-Politics Machine: “development”, depoliticization, and bureaucratic control in Lesotho, Cambridge University Press.

[3]. Hammar, Raftopoulos and Jensen (2003): Zimbabwe's unfinished Business. Rethinking Land, State and Nation in the Context of Crisis, Weaver Press, Harare

[4]. Harold Barry D (2004) The Past is the Future. Weaver Press, Harare

[5]. Herbst J (1990) State Politics in Zimbabwe. University of California Press. Berkeley

[6]. Herbst J (2000) States and Power in Africa. Comparative Lessons in Authority and Control. Princeton University Press, New Jersey

[7]. Hyden Goran (2006): African Politics in Comparative Perspective. Cambridge University Press, New York.

[8]. Mamdani Mahmood (1996): Citizen and Subject. Contemporary Africa and the Legacy of Late Colonialism. Princeton University Press, New Jersey.

[9]. Moyo Sam (1995) The Land Question in Zimbabwe. SAPES Books Harare

[10]. Moyo, Sam (1998): The Land Acquisition Process in Zimbabwe (1997/8). Harare: UNDP.

[11]. Moyo Sam, (2000a): The Political Economy of Land Acquisition and Redistribution in Zimbabwe; 1990-1999. Journal of Southern frican Studies, 26 (1) pp 5-28.

[12]. Moyo Sam (2000c). Land Reform Under Structural Adjustment in Zimbabwe. Land Use Change in the Mashonaland Provinces. Uppsala: Nordiska Afrikainstitutet.

[13]. Moore Donald S (2005) Suffering for territory: race, place and power in Zimbabwe Duke University Press USA.

[14]. Nyathi P (2001): Traditional Ceremonies of Amandebele. Mambo Press, Gweru.

[15]. Nyathi P (2000): Alvord Mabena. The Man and His Roots A Biography. Priority Projects Publishing, Harare.

[16]. Ranger T.O. (1999) Voices from the Rocks, nature, culture and history in the Matopos Hills of Zimbabwe. James Currey Ltd, Oxford.

[17]. Richard Joseph (ed. 1999): State, Conflict and Democracy in Africa. Lynne Reinner Publishers, Colorado.

[18]. Sithole T and Ruswa G (2003) The Zimbabwe Land Reform Programme. An audit of Public Perception. Konrad Adeneuer oundation Harare

[19]. West, H.G and Sanders T (ed. 2003): Transparency and Conspiracy: Ethnographies of Suspicion in the new world order. Duke University Press, Durham and London. 